\title{
TRIPLE SUPER PHOSPHATE AS A SOURCE OF PHOSPHORUS IN THE DIET OF GROWING BULL
}

\author{
A. Akter and Z. H. Khandaker
}

\begin{abstract}
The study was conducted to investigate the use of Triple Super Phosphate (TSP) as a source of phosphorus in growing cattle. Twelve indigenous growing bull (initial live weight of $150 \pm 10 \mathrm{~kg})$ were assigned to four dietary treatments, viz. basal diet $\left(\mathrm{T}_{0}\right)$ containing $0.14 \% \mathrm{P}$ and basal diet was supplemented with TSP to provide $\mathrm{P}$ levels of $0.24\left(\mathrm{~T}_{1}\right), 0.35\left(\mathrm{~T}_{2}\right)$ and $0.45 \%\left(\mathrm{~T}_{3}\right)$ respectively. All diets were formulated to be iso-nitrogenous and iso-energetic. Significant $(\mathrm{P}<0.05)$ differences in dry matter intake (DMI) were observed among the dietary treatments. The DMI ( $\mathrm{g} / \mathrm{d})$ of animals fed diet having $0.35 \% \mathrm{P}$ was higher than the diet containing $0.14,0.24$ and $0.45 \% \mathrm{P}$. The apparent digestibility of DM and OM were significantly $(\mathrm{P}<0.01)$ affected but $\mathrm{CP}$ and EE were not significantly $(\mathrm{P}>0.05)$ affected by the supplementation of $\mathrm{P}$ from TSP. The digestibility of CF and NFE was significantly $(\mathrm{P}<0.01)$ higher for diets $\mathrm{T}_{2}(0.35 \% \mathrm{P})$ compared to diet containing $0.14,0.24$ and $0.45 \% \mathrm{P}$. Apparent absorption of $\mathrm{P}$ was significantly $(\mathrm{P}<0.05)$ higher in animals fed on diet containing $0.14 \%$ phosphorous $\left(\mathrm{T}_{0}\right)$ than diets with 0.35 and $0.45 \%$ phosphorus and true absorption (g/100g) of $\mathrm{P}$ was significantly $(\mathrm{P}<0.01)$ higher in the animals fed on diets $\mathrm{T}_{0}(0.14 \% \mathrm{P})$ than those fed on other diets $\left(T_{1}, T_{2}\right.$ and $T_{3}$. Phosphorus balance was significantly $(P<0.01)$ higher for diets $T_{1}(4.37 \mathrm{~g} / \mathrm{d}), T_{2}(5.75 \mathrm{~g} / \mathrm{d})$ and $\mathrm{T}_{3}(7.09 \mathrm{~g} / \mathrm{d})$ compared to diet $\mathrm{T}_{0}(2.87 \mathrm{~g} / \mathrm{d})$ and highest value was observed on diet $\mathrm{T}_{3}$. There was no significant $(\mathrm{P}>0.05)$ difference among the mean values for live weight gain and the highest daily live weight gain was observed for diet $\mathrm{T}_{2}$ (69.44g) compared to the other diets $\mathrm{T}_{0}, \mathrm{~T}_{1}$ and $\mathrm{T}_{3}$ ). The average serum $P$ concentration of animals fed on diets $T_{1}, T_{2}$ and $T_{3}$ was significantly higher $(\mathrm{P}<0.01)$ than that of animal fed on diet $\mathrm{T}_{0}$. The results suggested that supplementation of TSP as a source of phosphorus increased total DMI, digestibility of CF, NFE, P retention, $\mathrm{P}$ content of blood serum and live weight gain of growing calves. Therefore, supplementation of $0.21 \% \mathrm{P}$ from TSP may be used in growing cattle ration.
\end{abstract}

Key words: Phosphorus, Triple super phosphate, Growing bull

\section{Introduction}

The primary role of phosphorus (P) is the integrity and development of the skeletal system. It is involved in almost every aspect of feed metabolism and utilization of fat, carbohydrate, protein and other nutrients in the body (Miller, 1985). It is also essential for proper functioning of rumen micro organisms, especially those that digest plant cellulose

Department of Animal Nutrition, Bangladesh Agricultural University, Mymensingh-2202, Bangladesh

(Received: October 04, 2010) 
Bang. J. Anim. Sci. 2010, 39(1\&2)

(McDowell, 1985). Phosphorus deficiency is most widespread and affects livestock production and health in many parts of the world including Bangladesh. The chronic deficiency of phosphorus in animal results in reduction of feed intake and organic matter digestibility, depraved appetite, low growth rates and reduced reproductive rates. Phosphorus deficiency can be prevented by direct treatment of the animal through supplementation of phosphorus or indirectly by appropriate fertilizer treatment of soils. Triple Super Phosphate (TSP) is a common source of supplemental phosphorus for crop production in our country. Bone meal and TSP are the important source of phosphorus in the cattle diet but no information regarding the level of phosphorus from TSP in diet is available for growing indigenous cattle. Therefore, the objectives of the present study was to investigate the supplementation of different level of TSP as a source of phosphorus and its response on the performance of indigenous growing cattle.

\section{Materials and Methods}

Twelve indigenous growing cattle (about 30 month of age) having initial live weight of $150 \pm 10 \mathrm{Kg}$ were used for a period of 60 days. The animals were divided into three blocks having four animals in each block. Four experimental diets were formulated with commonly available feed ingredients: rice straw, dhal grass, broken maize, soybean meal, urea and common salt. The control diet $\left(\mathrm{T}_{0}\right)$ contained $0.14 \% \mathrm{P}$. In addition to control diet $\left(\mathrm{T}_{0}\right)$, diets $\mathrm{T}_{1}, \mathrm{~T}_{2}$ and $\mathrm{T}_{3}$ were supplemented with $0.10,0.21,0.31 \% \mathrm{P}$ from TSP thus diets $\mathrm{T}_{1}, \mathrm{~T}_{2}$ and $\mathrm{T}_{3}$ contained $0.24,0.35$ and $0.45 \% \mathrm{P}$ respectively. All diets were iso-energetic and iso-nitrogenous and all four diets were randomly distributed in each block in a Randomized Block Design (RBD). The ingredient and nutrient composition of dietary treatments are shown in Table 1.

Daily feed intake was recorded. At the middle of the experiment, a metabolism trial was conducted for a period of 10 days for each treatment of which last seven days was collection period. Blood sample $(5 \mathrm{ml})$ of experimental animals were collected in the morning before offering feed and water by punching the jugular vein at 15 days interval. Feeds and faeces were analyzed for the proximate components according to the method of AOAC (1990). Phosphorus contents of feed ingredients, faeces, urine and blood sample were determined according to the method of Page et al. (1982). A daily balance was obtained by subtracting the total amount of $\mathrm{P}$ excreted in faeces and urine from the dietary $\mathrm{P}$ intake.

\section{Calculation}

Apparent and true absorption of $\mathrm{P}$ was calculated according to the following formula:

$$
\begin{aligned}
& \mathrm{AAP}=\frac{\mathrm{INTP}-(\text { FECP }- \text { ENDP })}{\text { INTP }} \times 100 \\
& \text { TAP }=\frac{\text { INTP }- \text { FECP }}{\text { INTP }} \times 100
\end{aligned}
$$


Triple super phosphate in the diet of bull

Here, $\quad$ AAP $=$ Apparent absorption of $\mathrm{P}(\mathrm{g} / 100 \mathrm{~g})$

TAP $=$ True absorption of $\mathrm{P}(\mathrm{g} / 100 \mathrm{~g})$

INTP $=$ Intake of $\mathrm{P}$ (g/day)

FECP $=$ Faecal excretion of $\mathrm{P}$ (g/day) and

ENDP $=$ Faecal endogenous excretion of $\mathrm{P}$

ARC (1980) model was used to predict faecal endogenous P excretion as:

$\mathrm{ENDP}=12 \mathrm{mg} / \mathrm{kg} \mathrm{LW} / \mathrm{d}$

Table 1. Ingredient and nutrient composition of the experimental diets

\begin{tabular}{|c|c|c|c|c|}
\hline \multirow[t]{2}{*}{ Parameters } & \multicolumn{4}{|c|}{ Dietary treatments } \\
\hline & $\mathrm{T}_{0}$ & $\mathrm{~T}_{1}$ & $\mathrm{~T}_{2}$ & $\mathrm{~T}_{3}$ \\
\hline \multicolumn{5}{|l|}{ Ingredients DM (kg/100 kg diet) } \\
\hline Rice straw & 33.34 & 33.34 & 33.34 & 33.34 \\
\hline Dhal grass & 36.67 & 36.67 & 36.67 & 36.67 \\
\hline Broken maize & 26.67 & 26.17 & 25.34 & 25.17 \\
\hline Soybean meal & 3.00 & 3.00 & 3.33 & 3.00 \\
\hline Urea & 0.16 & 0.16 & 0.16 & 0.16 \\
\hline Common salt & 0.16 & 0.16 & 0.16 & 0.16 \\
\hline Triple Super Phosphate & 0.00 & 0.50 & 1.00 & 1.50 \\
\hline \multicolumn{5}{|l|}{ Nutrient composition (g/100g DM) } \\
\hline CP & 8.26 & 8.26 & 8.30 & 8.26 \\
\hline CF & 28.64 & 28.37 & 28.19 & 28.60 \\
\hline $\mathrm{EE}$ & 1.96 & 1.98 & 1.98 & 1.97 \\
\hline NFE & 50.08 & 50.32 & 48.79 & 49.39 \\
\hline Ash & 11.06 & 11.07 & 12.14 & 11.78 \\
\hline $\mathrm{Ca}$ & 0.25 & 0.25 & 0.25 & 0.25 \\
\hline $\mathrm{P}$ & 0.14 & 0.24 & 0.35 & 0.45 \\
\hline Energy value* ME (MJ/kg DM) & 8.67 & 8.61 & 8.53 & 8.47 \\
\hline
\end{tabular}

${ }^{\#} \mathrm{~T}_{0}=$ Control $(0.14 \% \mathrm{P}), \mathrm{T}_{1}=$ Control $+\mathrm{TSP}(0.24 \% \mathrm{P}), \mathrm{T}_{2}=$ Control $+\mathrm{TSP}(0.35 \% \mathrm{P}) ; \mathrm{T}_{3}=$ Control $+\mathrm{TSP}$ $(0.45 \% \mathrm{P})$

The data were analyzed statistically using the analysis of variance in a Randomized Block Design (RBD). The least significance difference (LSD) was used to compare treatment means (Steel and Torrie, 1980).

\section{Results and Discussion}

The average feed and nutrient intake of growing bull fed different diets are shown in Table 2. Significant differences $(\mathrm{P}<0.05)$ in DMI were observed among the dietary treatments and DMI (g/d) of diet having $0.35 \%$ phosphorus $\left(T_{2}\right)$ was higher than the diets $T_{0}, T_{1}$ and $T_{3}$. 
Bang. J. Anim. Sci. 2010, 39(1\&2)

The results are in agreement with the findings of the experiment of Teh et al. (1982) and Langer et al. (1985). They reported that higher feed consumption by dairy calves was observed when dietary phosphorus was increased from 0.24 to $0.30 \%$ in diet, but when dietary P was increased to over $0.36 \%$ no further improvement was noticed. Jackson et al (1988) reported that feed intake was increased when dietary P was increased from 0.24 to $0.34 \%$. Other study showed that DM intake of cattle was increased when dietary P increased from 0.34 to $0.42 \%$ (Odongo et al., 2007). Use of TSP and monoammonium phosphate instead of dicalcium phosphate showed a significant increase on DMI of growing cattle (Barreto et al., 2009). Organic matter and CP intake were increased due to increasing levels of P from TSP but no significant differences were observed.

The digestibility of DM and OM were significantly $(\mathrm{P}<0.01)$ affected by the supplementation of P from different levels of TSP (Table 2). Witt and Ownes (1983) reported that digestibility of DM (64.8 vs $67.0 \%$ ) and $\mathrm{OM}$ (64.8 vs 66.9 ) were similar for 0.12 and $0.23 \%$ of dietary $\mathrm{P}$ respectively. A significant $(\mathrm{P}<0.01)$ difference of $\mathrm{CF}$ and NFE digestibility was observed in animals fed diet containing different levels $\left(\mathrm{T}_{1}, \mathrm{~T}_{2}\right.$ and $\left.\mathrm{T}_{3}\right)$ of P from TSP when compared with those fed control diet $\left(T_{0}\right)$. The values of crude fiber (CF) for diets $T_{2}$ containing $0.35 \% \mathrm{P}$ were significantly higher than that of $\mathrm{T}_{0}, \mathrm{~T}_{1}$ and $\mathrm{T}_{3}$. The digestibility of NFE was significantly $(\mathrm{P}<0.01)$ higher for diets $\mathrm{T}_{1}(0.24 \% \mathrm{P})$ and $\mathrm{T}_{2}(0.35 \% \mathrm{P})$ compared to that of diet $\mathrm{T}_{0}$ and $\mathrm{T}_{3}$. From this results it indicated that supplementation of $\mathrm{P}$ from TSP increased CF and NFE digestibility. The increase of CF and NFE digestibility in response to different levels of $\mathrm{P}$ supplementation could be attributing to the availability of extra $\mathrm{P}$ to rumen microbes which might have improved the rumen fermentation (Bryant et al., 1959). The significantly $(\mathrm{P}<0.01)$ higher $\mathrm{CF}$ and NFE digestibility of the diets supplemented with $\mathrm{P}$ (0.24 to $0.45 \%$ ) in the present study is in agreement with the statement of Ternouth et al. (1993) who reported that there was higher CF and NFE digestibility of the diets at higher P compared to low P diets. In contrast, Witt and Owens (1983) found no significant difference in the crude fiber digestibility of animals received P supplemented diets. They observed that acid detergent fiber and neutral detergent fiber digestibility were 55.2 vs 57.5 and 62.3 vs $65.3 \%$ for 0.12 and $0.23 \%$ dietary $\mathrm{P}$ level respectively. In this present experiment, the digestibility of $\mathrm{CP}$ and $\mathrm{EE}$ did not differ significantly $(\mathrm{P}>0.05)$.

The results of apparent and true absorption of $\mathrm{P}$ of the four dietary groups are shown in Table 3. The average daily $P$ intake was significantly $(P<0.01)$ difference among the treatments. The growing bull fed on diets $\mathrm{T}_{1}, \mathrm{~T}_{2}$ and $\mathrm{T}_{3}$ showed significantly $(\mathrm{P}<0.01)$ higher intake than the bull fed on diet $T_{0}$. The growing bulls fed on diets $T_{1}, T_{2}$ and $T_{3}$ showed significantly $(\mathrm{P}<0.01)$ higher faecal excretion than that of animals fed on diet $\mathrm{T}_{0}$. The urinary excretion of $\mathrm{P}$ was significantly $(\mathrm{P}<0.01)$ higher for treatment groups $\mathrm{T}_{1}(0.60 \mathrm{~g} / \mathrm{d}), \mathrm{T}_{2}(1.01$ $\mathrm{g} / \mathrm{d})$ and $\mathrm{T}_{3}(1.20 \mathrm{~g} / \mathrm{d})$ compared to the animals fed on diet $\mathrm{T}_{0}(0.49 \mathrm{~g} / \mathrm{d})$. The findings of the present study, is similar with observation of Morse et al. (1992) who reported that cows fed high $\mathrm{P}$ diet $(0.56 \% \mathrm{P})$ excreted significantly more $\mathrm{P}$ than the cows fed low $\mathrm{P}$ diets $(0.30 \% \mathrm{P})$. Wu et al. 2001 and Knowlton and Herbein (2002) observed increased faecal and urinary P excretion with increased of dietary P. Wu et al. (2003) reported that reducing dietary P from 0.42 to $0.33 \%$ resulted in approximately $25 \%$ less estimated faecal P excretion. It was found 
that apparent absorption of $\mathrm{P}$ was significantly $(\mathrm{P}<0.05)$ higher in animals fed on diet containing $0.14 \% \mathrm{P}\left(\mathrm{T}_{0}\right)$ than the animals fed on diet with 0.35 and $0.45 \% \mathrm{P}$. It can be seen from Table 3 that the true absorption of $\mathrm{P}(\mathrm{g} / 100 \mathrm{~g})$ was significantly $(\mathrm{P}<0.01)$ higher for dietary group $\mathrm{T}_{0}$ than $\mathrm{T}_{1}, \mathrm{~T}_{2}$ and $\mathrm{T}_{3}$.

Table 2. Effect of different levels of phosphorus on feed and nutrient intake and apparent digestibility of nutrients

\begin{tabular}{|c|c|c|c|c|c|c|}
\hline \multirow[t]{2}{*}{ Parameters } & \multicolumn{4}{|c|}{ Dietary treatments ${ }^{\#}$} & \multirow[t]{2}{*}{ SED } & \multirow{2}{*}{$\begin{array}{c}\text { Level of } \\
\text { Sig. }\end{array}$} \\
\hline & $\mathrm{T}_{0}$ & $\mathrm{~T}_{1}$ & $\mathrm{~T}_{2}$ & $\mathrm{~T}_{3}$ & & \\
\hline \multicolumn{7}{|l|}{ Intake (g/d) } \\
\hline \multicolumn{7}{|l|}{ Dry matter } \\
\hline Straw & 944 & 944 & 944 & 944 & - & - \\
\hline Concentrate & 734 & 734 & 734 & 734 & - & - \\
\hline Green grass & 1872.0 & 1989.4 & 2037.4 & 1936.0 & - & - \\
\hline Total DM & $3550^{\mathrm{d}}$ & $3667^{\mathrm{b}}$ & $3715^{\mathrm{a}}$ & $3614^{c}$ & 21 & $*$ \\
\hline Total OM & 2795 & 2882 & 2917 & 3174 & 94 & NS \\
\hline Total CP & 226 & 229 & 231 & 229 & 0.90 & NS \\
\hline \multicolumn{7}{|c|}{ Apparent digestibility (g/100g) } \\
\hline $\mathrm{DM}$ & $54.87^{\mathrm{b}}$ & $64.02^{\mathrm{a}}$ & $64.35^{\mathrm{a}}$ & $62.49^{\mathrm{ab}}$ & 1.20 & $* *$ \\
\hline OM & $57.27^{\mathrm{b}}$ & $66.15^{\mathrm{a}}$ & $67.38^{\mathrm{a}}$ & $68.45^{\mathrm{a}}$ & 1.43 & $* *$ \\
\hline $\mathrm{CP}$ & 53.64 & 57.76 & 58.75 & 57.86 & 1.10 & NS \\
\hline $\mathrm{CF}$ & $60.27^{\mathrm{C}}$ & $70.45^{\mathrm{bc}}$ & $75.21^{\mathrm{a}}$ & $72.20^{\mathrm{b}}$ & 1.75 & $* *$ \\
\hline $\mathrm{EE}$ & 50.76 & 56.06 & 51.48 & 51.77 & 0.90 & NS \\
\hline NFE & $57.57^{\mathrm{C}}$ & $67.59^{\mathrm{a}}$ & $66.53^{\mathrm{a}}$ & $64.58^{\mathrm{b}}$ & 1.26 & $* *$ \\
\hline
\end{tabular}

${ }^{\#} \mathrm{~T}_{0}=$ Control $(0.14 \% \mathrm{P}), \mathrm{T}_{1}=$ Control $+\mathrm{TSP}(0.24 \% \mathrm{P}), \mathrm{T}_{2}=$ Control $+\mathrm{TSP}(0.35 \% \mathrm{P})$ and $\mathrm{T}_{3}=$ Control + TSP (0.45\% P)

SED $=$ Standard error of difference; NS $=\mathrm{P}>0.05, *=\mathrm{P}<0.05, * *=\mathrm{P}<0.01$

a,b,c,d Mean values having different superscripts in a row differ significantly $(\mathrm{P}<0.05)$

All the bulls used in this experiment showed positive P balance. It can be observed from the Table 3 that the $\mathrm{P}$ balance was significantly $(\mathrm{P}<0.01)$ higher for supplemental diets $\mathrm{T}_{1}(4.37$ $\mathrm{g} / \mathrm{d}), \mathrm{T}_{2}(5.75 \mathrm{~g} / \mathrm{d})$ and $\mathrm{T}_{3}(7.09 \mathrm{~g} / \mathrm{d})$ compared to non supplemental diet $\left(\mathrm{T}_{0}(2.87 \mathrm{~g} / \mathrm{d})\right.$. The $\mathrm{P}$ balance for the animals fed on diet $\mathrm{T}_{3}$ was significantly $(\mathrm{P}<0.01)$ higher than that of animals fed on diets $T_{1}$ and $T_{2}$. The daily $P$ retention $(g / 100 g$ intake) was significantly $(P<0.05)$ higher for the animals fed on diets $T_{0}(55.75)$ than $T_{2}(54.19)$ and $T_{3}(53.76)$ and diets $T_{0}, T_{1}$ and $\mathrm{T}_{2}$ than diet $\mathrm{T}_{3}$.

No significant $(\mathrm{P}>0.05)$ difference was observed on live weight gain among the treatment groups although the animals fed on diet containing $0.35 \% \mathrm{P}$ was apparently higher compared 
Bang. J. Anim. Sci. 2010, 39(1\&2)

to $0.15\left(\mathrm{~T}_{0}\right), 0.24\left(\mathrm{~T}_{1}\right)$ and $0.45 \%\left(\mathrm{~T}_{3}\right) \mathrm{P}$ (Table 4). A number of response criteria have been used to evaluate the $\mathrm{P}$ status of cattle of which serum $\mathrm{P}$ level is one of them. Normal values for plasma $\mathrm{P}$ is $4-5 \mathrm{mg} / 100 \mathrm{ml}$ for adults and somewhat higher, often $6-8 \mathrm{mg} / 100 \mathrm{ml}$ for very young animals. Plasma P values below $4.5 \mathrm{mg} / 100 \mathrm{ml}$ in cattle is indicative of P deficiency (McDowell, 1992). In this study mean serum $\mathrm{P}$ concentration is affected by the supplementation of $\mathrm{P}$ and increased significantly $(\mathrm{P}<0.01)$ with higher $\mathrm{P}$ diet.

Table 3. Effect of different levels of phosphorus on apparent and true absorption of phosphorus from different dietary treatments

\begin{tabular}{|c|c|c|c|c|c|c|}
\hline \multirow[t]{2}{*}{ Parameters } & \multicolumn{4}{|c|}{ Dietary treatments $^{\#}$} & \multirow[t]{2}{*}{ SED } & \multirow{2}{*}{$\begin{array}{l}\text { Level } \\
\text { of Sig. }\end{array}$} \\
\hline & $\mathbf{T}_{\mathbf{0}}$ & $\mathbf{T}_{1}$ & $\mathbf{T}_{2}$ & $\mathbf{T}_{3}$ & & \\
\hline Phosphorus intake (g/d) & $5.16^{\mathrm{d}}$ & $7.77^{\mathrm{c}}$ & $10.61^{\mathrm{b}}$ & $13.19^{\mathrm{a}}$ & 0.91 & $* *$ \\
\hline Faecal P excretion (g/d) & $1.80^{\mathrm{d}}$ & $2.80^{c}$ & $3.85^{\mathrm{b}}$ & $4.90^{\mathrm{a}}$ & 0.35 & ** \\
\hline Urinary P excretion (g/d) & $0.49^{\mathrm{d}}$ & $0.60^{\mathrm{c}}$ & $1.01^{\mathrm{b}}$ & $1.20^{\mathrm{a}}$ & 0.08 & $* *$ \\
\hline Total P excretion (g/d) & $2.29^{\mathrm{d}}$ & $3.40^{\mathrm{c}}$ & $4.86^{\mathrm{b}}$ & $6.10^{\mathrm{a}}$ & 0.44 & $* *$ \\
\hline Faecal endogenous P excretion (g/d) & 1.70 & 1.57 & 1.73 & 1.70 & 0.08 & NS \\
\hline Apparent absorption (g/100g) & $65.20^{\mathrm{a}}$ & $63.96^{\mathrm{ab}}$ & $63.71^{\mathrm{b}}$ & $62.85^{\mathrm{b}}$ & 0.31 & $*$ \\
\hline True absorption (g/100g) & $98.04^{\mathrm{a}}$ & $84.46^{b}$ & $80.05^{\mathrm{bc}}$ & $75.74^{\mathrm{C}}$ & 2.59 & $* *$ \\
\hline Phosphorus balance (g/d) & $2.87^{\mathrm{d}}$ & $4.37^{c}$ & $5.75^{\mathrm{b}}$ & $7.09^{\mathrm{a}}$ & 0.47 & $* *$ \\
\hline Phosphorus retention (g/100g) & $55.75^{\mathrm{ab}}$ & $56.24^{\mathrm{a}}$ & $54.19^{\mathrm{bc}}$ & $53.76^{\mathrm{C}}$ & 0.38 & $*$ \\
\hline
\end{tabular}

${ }^{\#} \mathrm{~T}_{0}=$ Control $(0.14 \% \mathrm{P}), \mathrm{T}_{1}=$ Control $+\mathrm{TSP}(0.24 \% \mathrm{P}), \mathrm{T}_{2}=$ Control $+\mathrm{TSP}(0.35 \% \mathrm{P}), \mathrm{T}_{3}=$ Control $+\mathrm{TSP}$ $(0.45 \% \mathrm{P}) ; \mathrm{NS}=\mathrm{P}>0.05, *=\mathrm{P}<0.05, * *=\mathrm{P}<0.01$

$\mathrm{SED}=$ Standard error of difference

a,b,c,d Mean values having different superscripts in a row differ significantly $(\mathrm{P}<0.01, \mathrm{P}<0.05)$

It can be seen from the Table 5 that the average blood serum $\mathrm{P}$ concentration of growing bulls on diet $\mathrm{T}_{3}(0.45 \% \mathrm{P})$ was significantly $(\mathrm{P}<0.01)$ higher than those on diet $\mathrm{T}_{1}(0.24 \% \mathrm{P})$ and $\mathrm{T}_{2}(0.35 \% \mathrm{P})$ at different collection periods. The average serum $\mathrm{P}$ concentration of animals of four collection periods was 4.42, 5.86, 6.57 and $7.33 \mathrm{mg} / \mathrm{dl}$ for diets $\mathrm{T}_{0}, \mathrm{~T}_{1}, \mathrm{~T}_{2}$ and $\mathrm{T}_{3}$ respectively and significant $(\mathrm{P}<0.01)$ difference between the control group and supplemented groups was observed. Williams et al. (1991) and Jain and Chopre (1994) reported a good evidence for an increased serum $\mathrm{P}$ concentration due to a high $\mathrm{P}$ intake by cattle. They observed that supplementation of different levels of $\mathrm{P}$ in the diet of cattle increased blood serum inorganic $\mathrm{P}$ concentrations. It was also shown that serum $\mathrm{P}$ concentrations were elevated when phosphorus was supplemented in the diet of growing calves (Ingalls and Okemo, 1994).

The results suggested that supplementation of TSP as a source of phosphorus increased total DMI, apparent digestibility of CF and NFE, apparent and true absorption of phosphorus, $\mathrm{P}$ retention, $\mathrm{P}$ content of blood serum and live weight gain of growing calves. Based on the above findings it may be concluded that supplementation of $0.31 \%$ P from TSP may be used in growing bull calves ration. 
Triple super phosphate in the diet of bull

Table 4. Effect of different levels of phosphorus on growth performance of growing cattle

\begin{tabular}{l|l|c|c|c|c|c|c|}
\hline \multirow{2}{*}{ Parameters } & \multicolumn{3}{c|}{ Dietary treatments } & SED & $\begin{array}{c}\text { Level } \\
\text { of Sig. }\end{array}$ \\
\cline { 2 - 6 } & $\mathbf{T}_{\mathbf{0}}$ & $\mathbf{T}_{\mathbf{1}}$ & $\mathbf{T}_{\mathbf{2}}$ & $\mathbf{T}_{\mathbf{3}}$ & & \\
\hline Initial live weight (kg) & 147.8 & 144.8 & 146.8 & 144.5 & 6.42 & $\mathrm{NS}$ \\
Final live weight (kg) & 150.0 & 147.3 & 151.0 & 146.0 & 6.35 & $\mathrm{NS}$ \\
Total live weight gain (LWG) (kg) & 2.16 & 2.50 & 4.16 & 1.50 & 0.38 & $\mathrm{NS}$ \\
Daily live weight gain (LWG) (g) & 36.11 & 41.66 & 69.44 & 25.00 & 6.47 & $\mathrm{NS}$ \\
LWG (kg/100 kg BW) & 1.52 & 1.73 & 2.83 & 1.23 & 0.27 & $\mathrm{NS}$ \\
LWG (g/kgW ${ }^{0.75}$ ) & 1.73 & 1.98 & 2.91 & 1.30 & 0.23 & $\mathrm{NS}$ \\
Feed Conversion efficiency (DMI/LWG) & 3.17 & 2.13 & 1.28 & 5.18 & 0.73 & $\mathrm{NS}$ \\
Protein Conversion efficiency (CPI/LWG) & 0.14 & 0.09 & 0.06 & 0.68 & 0.42 & $\mathrm{NS}$ \\
\hline
\end{tabular}

Table 5. Serum phosphorus level (mg/dl) in animals fed different experimental diets

\begin{tabular}{|c|c|c|c|c|c|c|}
\hline \multirow{2}{*}{$\begin{array}{l}\text { Blood collection } \\
\text { (weeks) }\end{array}$} & \multicolumn{4}{|c|}{ Dietary treatments ${ }^{\#}$} & \multirow[t]{2}{*}{ SED } & \multirow[t]{2}{*}{ Level of Sig. } \\
\hline & $\mathbf{T}_{\mathbf{0}}$ & $\mathbf{T}_{1}$ & $\mathbf{T}_{2}$ & $\mathbf{T}_{3}$ & & \\
\hline 0 & 4.33 & 4.27 & 4.35 & 4.36 & 0.013 & NS \\
\hline $2^{\text {nd }}$ & $4.20^{\mathrm{d}}$ & $5.74^{\mathrm{c}}$ & $6.53^{b}$ & $7.18^{\mathrm{a}}$ & 0.34 & $* *$ \\
\hline $4^{\text {th }}$ & $4.47^{\mathrm{d}}$ & $5.69^{\mathrm{c}}$ & $6.47^{\mathrm{b}}$ & $7.35^{\mathrm{a}}$ & 0.32 & $* *$ \\
\hline $6^{\text {th }}$ & $4.45^{\mathrm{d}}$ & $5.67^{c}$ & $6.53^{b}$ & $7.33^{\mathrm{a}}$ & 0.32 & $* *$ \\
\hline $8^{\text {th }}$ & $4.55^{\mathrm{d}}$ & $6.35^{c}$ & $6.75^{\mathrm{b}}$ & $7.45^{\mathrm{a}}$ & 0.32 & $* *$ \\
\hline Mean @ & $4.42^{\mathrm{d}}$ & $5.86^{\mathrm{c}}$ & $6.57^{\mathrm{b}}$ & $7.33^{\mathrm{a}}$ & 0.32 & $* *$ \\
\hline
\end{tabular}

${ }^{\#} \mathrm{~T}_{0}=$ Control $(0.14 \% \mathrm{P}), \mathrm{T}_{1}=$ Control $+\mathrm{TSP}(0.24 \% \mathrm{P}), \mathrm{T}_{2}=$ Control $+\mathrm{TSP}(0.35 \% \mathrm{P}), \mathrm{T}_{3}=$ Control $+\mathrm{TSP}$ $(0.45 \% \mathrm{P})$

SED $=$ Standard error of difference; NS $=\mathrm{P}>0.05, * *=\mathrm{P}<0.01$

a,b,c,d Mean values having different superscripts in a row differ significantly $(\mathrm{P}<0.01)$

Mean ${ }^{@}=$ Last 4 collection

\section{Literature Cited}

AOAC, 1990. Official Methods of Analysis. $15^{\text {th }}$ Ed. Association of Official Analytical Chemists, Arlington, Virginia USA.

ARC, 1980. The Nutrient Requirements of Ruminant Livestock. Common wealth Agricultural Bureaux. Slough, UK.

Barreto, J. C., Branco, A. F., Santos, G. T. dos., Magalhaes, V. J. de. A., Coneglian, S. M and Teixeira, S. 2009. Evaluation of different phosphorus sources in the diet on ruminal parameters, microbial synthesis, nutrient apparent digestibility and plasma phosphorus in cattle. J. Anim. Sci. 2009, 38(4): 760-769. 
Bang. J. Anim. Sci. 2010, 39(1\&2)

Ingalls, J. R. and Okemo, R. C. 1994. The bioavailability of phosphorus from canola meal as measured by Holstein calves and mobile bag technique. Animal Feed Sci. \& Tech., 47: 321-334.

Jain, R. K. and Chopra, R. C. 1994. Effect of feeding low phosphorus diet on feed intake, nutrient utilization, growth and certain blood parameters in calves. Indian. J. Anim. Nutr., 11(4): 205-210.

Jackson, J. A., Langer, D. L. and Hemiken, R. W. 1988. Evaluation of content and source of phosphorus fed to dairy calves. J. Dairy Sci., 71: 2187-2192.

Knowlton, K. F. and Herbein, J. H. 2002. Phosphorus partitioning during early lactation in dairy cows fed diets varying in phosphorus content. J. Dairy Sci., 2002; 85(5): 1227-1236

Langer, D. L., Jackson, J. A., Hemken, R. W. and Harmon, R. J. 1985. Effect of level and source of phosphorus fed to dairy calves. (Abstr). J. Dairy Sci., 68: 136.

McDowell, L. R. 1985. Calcium, phosphorus and fluorine. In: Nutrition of grazing Ruminants in warm climates (Editors: McDowell) Academic press, Orlando, Florida, pp. 216-241.

McDowell, L. R. 1992. Mineral in animal and human nutrition. Academic Press, San Diago, Californi, 92101-4495.

Miller, W. J. 1985. In Calcium and phosphorus in animal nutrition. National Feed Ingredient Association (NFIA), West Des Moines, Iowa.

Morse, D. H., Head, H. H. and Wilcox, C. C. J. 1992. Disappearance of phosphorus in phytate from concentrates in vitro and from rations fed to lactating dairy cows. J. Dairy Sci., 75: 1979-1986.

Odongo, N. E., McKnight, D., KoekKoek, A., Fisher, J. W., Sharpe, P., Kebreab, E., France, J. and McBride, B. W. 2007. Long-term effects of feeding diets without mineral phosphorus supplementation on the performance and phosphorus excretion in high-yielding dairy cows. Canadian J. Anim. Sci., 2007; 87(4): 639-646.

Page, A. L., Miller, R. H. and Keeney, D. R. 1982. Method of soil analysis. Part-2. Amer. Soc. Agron. Inc. Soil So. Soc. Amer. Inc. Madison Vriseconsin, USA. pp. 152-531.

Steel, R. G. D. and Torrie, J. A. 1980. Principles and procedures of statistics. McGraw Hill, New York, pp. 120.

Teh, T. H., Hemken, R. W. and Bull, L. S. 1982. Evaluation of urea ammonium poly phosphate as a phosphorus source for dairy calves. J. Anim. Sci., 55: 174.

Witt, K. E. and Owens, F. N. 1983. Phosphorus: Ruminal availability and effects on digestion. J. Anim. Sci., 50: 930-937.

Williams, S. N., McDowell, L. R., Warrick, A. C., Wilkinson, N. S. and Lawresnce, L. A. 1991. Phosphorus concentration in blood, milk, feces, bone and selected fluids and tissues of growing heifers as affected by dietary phosphorus. Fla. Beef Cattle Res. Rep. Fla. Coop. Ext. Serv. Univ. Fla, pp. 118-121.

Wu, Z., Satter, L. D., Blohowiak, A. J., Stauffacher, R. H. and Wilson, J. H. 2001. Milk production, estimated phosphorus excretion, and bone characteristics of dairy cows fed different amounts of phosphorus for two or three years. J. Dairy Sci., 84: 1738-1748.

Wu, Z., Tallam, S. K., Ishler, V. A. and Archibald, D. D. 2003. Utilization of phosphorus in lactating cows fed varying amounts of phosphorus and forage. J. Dairy Sci., 2003; 86(10): 3300-3308. 